\title{
Characterization of preferential flow paths between boreholes in fractured rock using a nanoscale zero-valent iron tracer test
}

\author{
Po-Yu Chuang ${ }^{1}$ - Yeeping Chia ${ }^{1}$ - Ya-Hsuan Liou ${ }^{1}$ Mao-Hua Teng ${ }^{1}$ Ching-Yi Liu ${ }^{1}$. \\ Tsai-Ping Lee ${ }^{2}$
}

Received: 29 October 2015 / Accepted: 6 May 2016 / Published online: 30 May 2016

(C) The Author(s) 2016. This article is published with open access at Springerlink.com

\begin{abstract}
Recent advances in borehole geophysical techniques have improved characterization of cross-hole fracture flow. The direct detection of preferential flow paths in fractured rock, however, remains to be resolved. In this study, a novel approach using nanoscale zero-valent iron (nZVI or 'nano-iron') as a tracer was developed for detecting fracture flow paths directly. Generally, only a few rock fractures are permeable while most are much less permeable. A heat-pulse flowmeter can be used to detect changes in flow velocity for delineating permeable fracture zones in the borehole and providing the design basis for the tracer test. When nano-iron particles are released in an injection well, they can migrate through the connecting permeable fracture and be attracted to a magnet array when arriving in an observation well. Such an attraction of incoming iron nanoparticles by the magnet can provide quantitative information for locating the position of the tracer inlet. A series of field experiments were conducted in two wells in fractured rock at a hydrogeological research station in Taiwan, to test the cross-hole migration of the nano-iron tracer through permeable connected fractures. The fluid conductivity recorded in the observation well confirmed the arrival of the injected nano-iron slurry. All of the
\end{abstract}

Electronic supplementary material The online version of this article (doi:10.1007/s10040-016-1426-7) contains supplementary material, which is available to authorized users.

Yeeping Chia

ypc@ntu.edu.tw

1 Department of Geosciences, National Taiwan University, No. 1, Sec. 4, Roosevelt Rd., Taipei 106, Taiwan

2 Sinotech Engineering Consultants, Inc., No. 280, Xinhu 2nd Rd., Taipei 114, Taiwan iron nanoparticles attracted to the magnet array in the observation well were found at the depth of a permeable fracture zone delineated by the flowmeter. This study has demonstrated that integrating the nano-iron tracer test with flowmeter measurement has the potential to characterize preferential flow paths in fractured rock.

Keywords Fractured rocks · Preferential flow $\cdot$ Flowmeter · Nanoscale zero-valent iron · Tracer tests

\section{Introduction}

Characterization of preferential flow in fractured rock is a challenge for the management of water resources, geotechnical engineering, waste disposal, and groundwater remediation, as well as petroleum and geothermal production. Fluid flow in rock fractures has been studied in the past with observations and numerical simulations (NRC 1996; Neuman 2005; Van Meir et al. 2007). Fracture zones in a borehole can be identified by core log or acoustic televiewer imaging (Barton et al. 1995; Williams and Johnson 2000), but groundwater is often found to flow through only a few permeable fractures, especially in crystalline rock (Zhao 1998; Swanson et al. 2006); hence, delineation of permeable fractures is essential to the characterization of preferential flow paths in rock formations.

Packer tests have been used to investigate permeable fracture zones in an open hole (Braester and Thunvik 1984; Zhao 1998), but the test process is time-consuming and the depth resolution is restricted by the test interval. Flowmeter tests can be used to better characterize the vertical distribution of permeability in the borehole, providing more detailed information for the design of any tracer test and the interpretation of fracture flow pathways (Hess 1986; Williams and Paillet 2002; Lee et al. 2012; Basirico et al. 2015). A temperature 
tomography experiment has been developed to investigate transmissive fractures and cross-hole preferential flow (Read et al. 2013; Klepikova et al. 2014; Coleman et al. 2015). This technique can provide qualitative information of flow paths; however, the main flow pathway interpreted from the thermal tracer can be somewhat different from the pathway found using the solute tracer (Read et al. 2013). Apparently, field characterization of fracture flow paths demands a more direct quantitative technique.

Tracer tests have long been used to evaluate the crosshole connectivity in fractured rock (Chen 1986; Novakowski and Lapcevic 1994; Sharifi Haddad et al. 2015); however, the test results have not shown the exact location of the tracer inlet in the observation well. Nanoscale zero-valent iron (nZVI) has been widely applied to in-situ remediation of groundwater contamination (Wang and Zhang 1997; Varanasi et al. 2007). Iron is a magnetic material which can be attracted by a magnet. Previous studies revealed that iron nanoparticles would be highly mobile and remain in suspension for days to months in unconsolidated deposits (Sun et al. 2007; Comba and Sethi 2009; Bennett et al. 2010; He et al. 2010).

In this study, a novel approach using nZVI as a tracer was developed, aiming to directly detect flow paths in fractured rock. A series of preliminary experiments, including crosshole hydraulic tests (to select suitable boreholes) and heatpulse flowmeter measurements (to delineate permeable zones) were conducted at a hydrogeological research station to provide the design basis for the tracer test. During the nZVI (or 'nano-iron') tracer test, the magnet array and the fluid conductivity sensor were used to monitor the incoming iron nanoparticles and the arrival of nano-iron slurry in the observation well. The test was intended to directly locate incoming fracture flow paths and interpret hydraulic parameters of the connective fracture between boreholes. Advantages, disadvantages and further improvement of this preliminary nano-iron tracer test are discussed.

\section{Field experiments}

\section{Hydrogeological research station}

Field experiments were conducted at the hydrogeological research station at Heshe Experimental Forest of the National Taiwan University in central Taiwan (Fig. 1). The elevation of the station is approximately $775 \mathrm{~m}$ above sea level. The site is located approximately $100 \mathrm{~m}$ west of Chenyoulan River. The peak of Mt. Wangma, where the elevation is $1,427 \mathrm{~m}$ above sea level, is located $1.7 \mathrm{~km}$ to the west of the station; thus, the shallow groundwater tends to flow from the west to the east. The water table at the station is about $9 \mathrm{~m}$ below the ground surface.
Three experimental wells installed in fractured rock at the research station were used to conduct various tests. The specifications of the three experimental wells are shown in Table S1 of the electronic supplementary material (ESM). The depth of these wells is about $25 \mathrm{~m}$ and the distance between the wells is $2.4-3.3 \mathrm{~m}$, as shown in Fig. 2. The overburden, ranging from the surface to $12.7-13.8 \mathrm{~m}$ depth, is primarily composed of terrace deposits and colluvium, including sand, gravel and weathered rock debris. It is underlain by the Juifang group consisting of fractured dark grey shale and siltstone. These wells are cased and sealed to $1.7-2.3 \mathrm{~m}$ below the overburden to prevent groundwater in the overburden from flowing into the borehole (Fig. 2). The experimental wells remained open below the casing section.

\section{Hydraulic test}

Hydraulic tests were conducted to investigate the cross-hole hydraulic connectivity for selecting suitable tracer test wells. During the first test, well $\mathrm{C}$ was used as a pumping well and wells A and B were adopted as observation wells. Pumping was conducted at a constant rate of $173.7 \mathrm{ml} / \mathrm{s}$ for about $11 \mathrm{~min}$ and then stopped (Fig. 3a). The water level at well A declined $17.8 \mathrm{~cm}$ approximately $45 \mathrm{~min}$ after pumping, and then started to recover (Fig. 3b). The water level at well B declined slightly and no significant recovery was observed after pumping stopped. The test results indicated good hydraulic connection between wells $\mathrm{C}$ and $\mathrm{A}$, but poor connection between wells $\mathrm{C}$ and $\mathrm{B}$.

The second cross-hole hydraulic test was conducted to verify the hydraulic connection between well A and well C. The maximum drawdown at the pumping well $\mathrm{A}$ was $12.3 \mathrm{~m}$ (Fig. 4a). While no significant drawdown was observed at well $\mathrm{B}$, the water level declined up to $40 \mathrm{~cm}$ at well $\mathrm{C}$ (Fig. 4b). The second test results further confirmed hydraulic connection between wells A and C; therefore, well A and well $\mathrm{C}$ were selected to conduct the tracer test for characterizing cross-hole preferential flow paths.

In addition, analysis of hydraulic test data is performed to estimate the transmissivity of rock formation in the open-hole section of the well. Since approximately $60-70 \%$ of the pumped water is derived from wellbore storage, the drawdown data of the pumping well was analyzed using the solution for a well with a large diameter (Papadopulos and Cooper 1967)

$S_{\mathrm{w}}=Q / 4 \pi T F\left(u_{\mathrm{w}}, \alpha\right)$

where $S_{\mathrm{w}}$ is the drawdown at time $t, Q$ is the pumping rate, and $T$ is the transmissivity of the rock formation. The $F\left(u_{\mathrm{w}}, \alpha\right)$ is the integral function that accounts for the pumping well pipe storage effect and can be determined by matching the mathematical model of Papadopulos and Cooper (1967) solution to drawdown data. Thus, the estimated transmissivity of the rock 


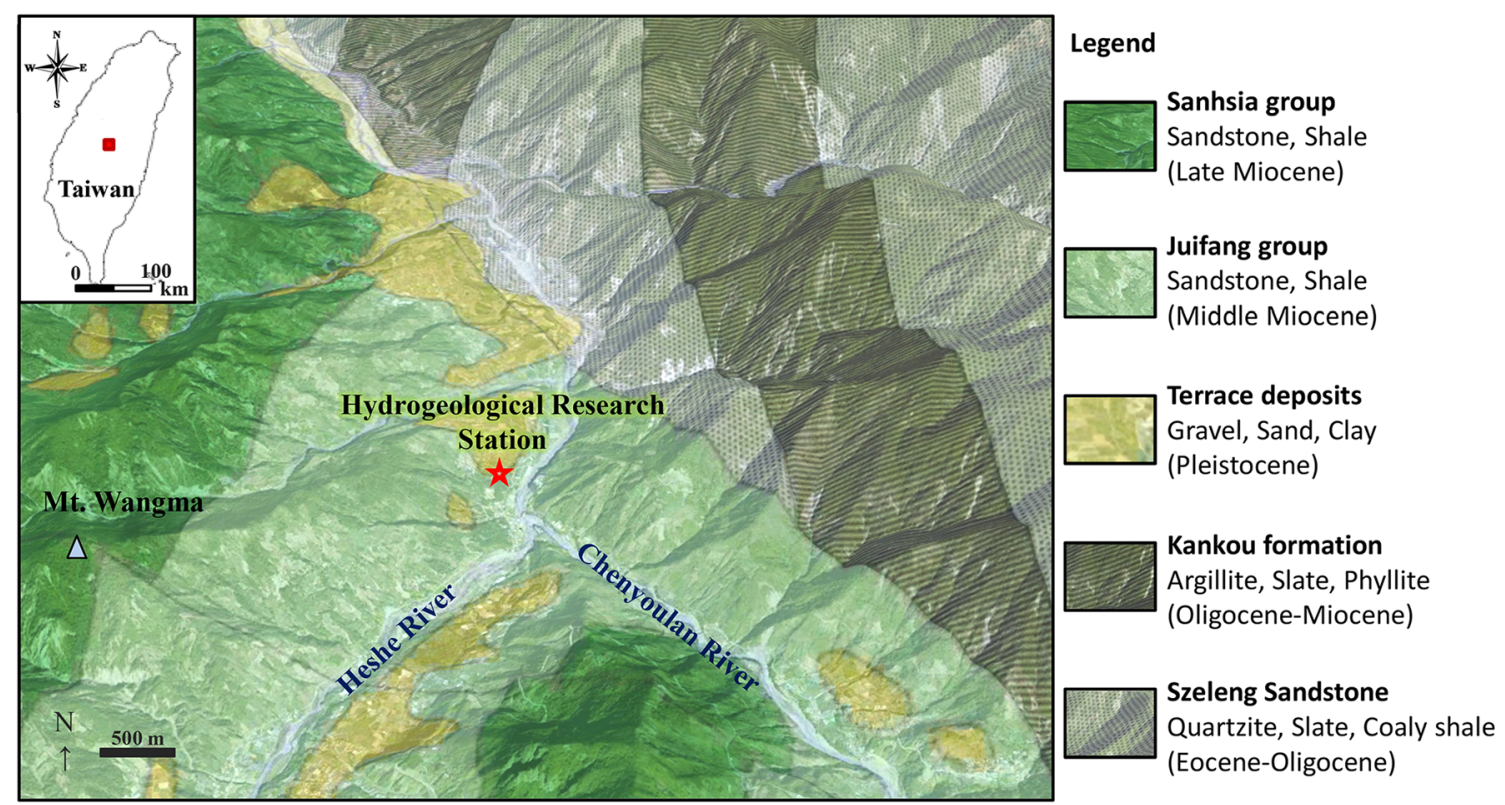

Fig. 1 Geologic map showing the location of the hydrogeological research station where the field tests were conducted (modified from the Central Geological Survey and Google map)

formation in the open-hole section of wells $\mathrm{A}$ and $\mathrm{C}$ are $4.33 \times 10^{-7}$ and $2.47 \times 10^{-7} \mathrm{~m}^{2} / \mathrm{s}$, respectively. Since the hydraulic tests were conducted over a short period of time, the estimated values are likely to represent the ease of fracture flow in the immediate vicinity of the wells, instead of a nearby area.

\section{Distribution of rock fractures}

Although the preferential flow path between wells $\mathrm{A}$ and $\mathrm{C}$ is likely to connect through some fractures, it is often difficult to know the exact location of these permeable fractures. Zones of high fracture density are often assumed to be permeable

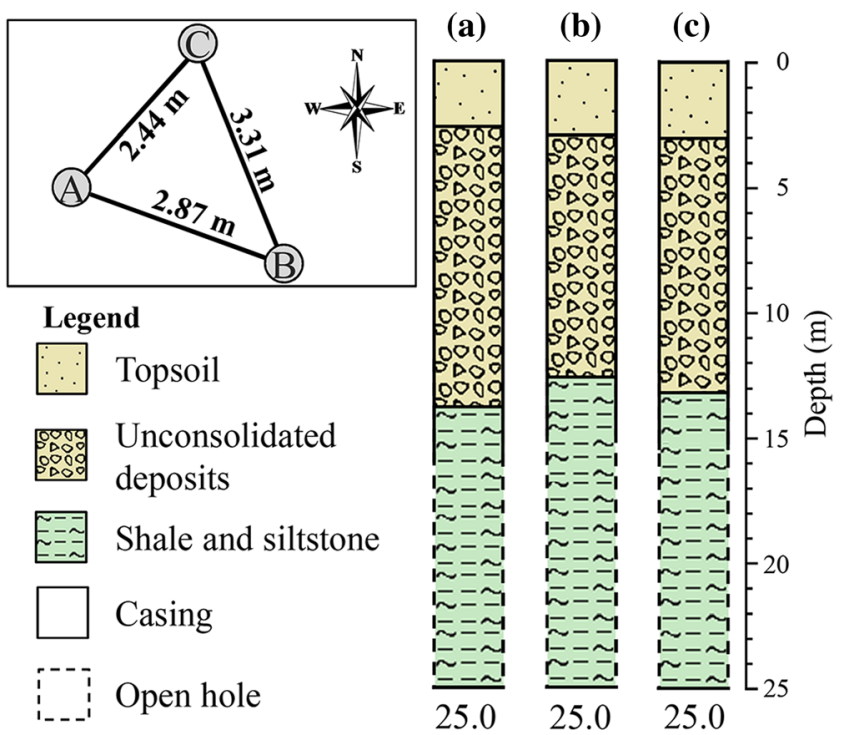

Fig. 2 Stratigraphic columns of experimental wells $(\mathbf{a}-\mathbf{c})$, and distance between wells at the hydrogeological research station
(Barton et al. 1995; Williams and Johnson 2000). It is possible to identify zones of high fracture density from the drill core based on the distribution of the fracture index, defined as the number of fractures per meter length of solid core recovered. In well $\mathrm{A}$, the fracture index varies from 4 to 45 (Fig. 5). The highest index appears in the core at the depth of 17-18 $\mathrm{m}$. The fracture system was also characterized using an acoustic borehole televiewer image. Zones of high fracture density were identified at the depths of 17.3-18.0, 19.6-20.3, 21-21.2, and $21.6-21.8 \mathrm{~m}$ in well A. Similarly, high fracture density is found at the depths of 16.4-16.5, 17.2-17.5, 19.2-20, 20.220.3, 22.7-22.8 and 23.5-24.1 $\mathrm{m}$ in well C (Fig. 6).

\section{Heat-pulse flowmeter measurement}

Heat-pulse flowmeter measurements were adopted to investigate the permeable zones in wells $\mathrm{A}$ and $\mathrm{C}$, providing the design basis for the nano-iron tracer test. The flowmeter test started with the measurement of ambient flow in the borehole. As the ambient flow could not be detected in wells A and C, the vertical hydraulic gradient in the borehole was very small and could be ignored; thus, all individual layers under steady-state conditions were assumed to have a similar hydraulic head. Well A was then pumped at $31.6 \mathrm{ml} / \mathrm{s}$ to induce a vertical borehole flow. After the drawdown reached a steady state approximately $4 \mathrm{~h}$ later, the flowmeter measurements were performed in the open-hole section between 16 and $22 \mathrm{~m}$ depth. The measurement interval ranged between 25 and $100 \mathrm{~cm}$, depending on the change of measured flow (Fig. 5). A significant error in the measured velocity, particularly at a low flow velocity, is caused by the free convection and the shape factor associated with the irregular flow-through cell of the heat-pulse flowmeter. The 
Fig. 3 Drawdown versus time for the first hydraulic test at a the pumping well $\mathbf{C}$ and $\mathbf{b}$ observation wells $\mathrm{A}$ and $\mathrm{B}$

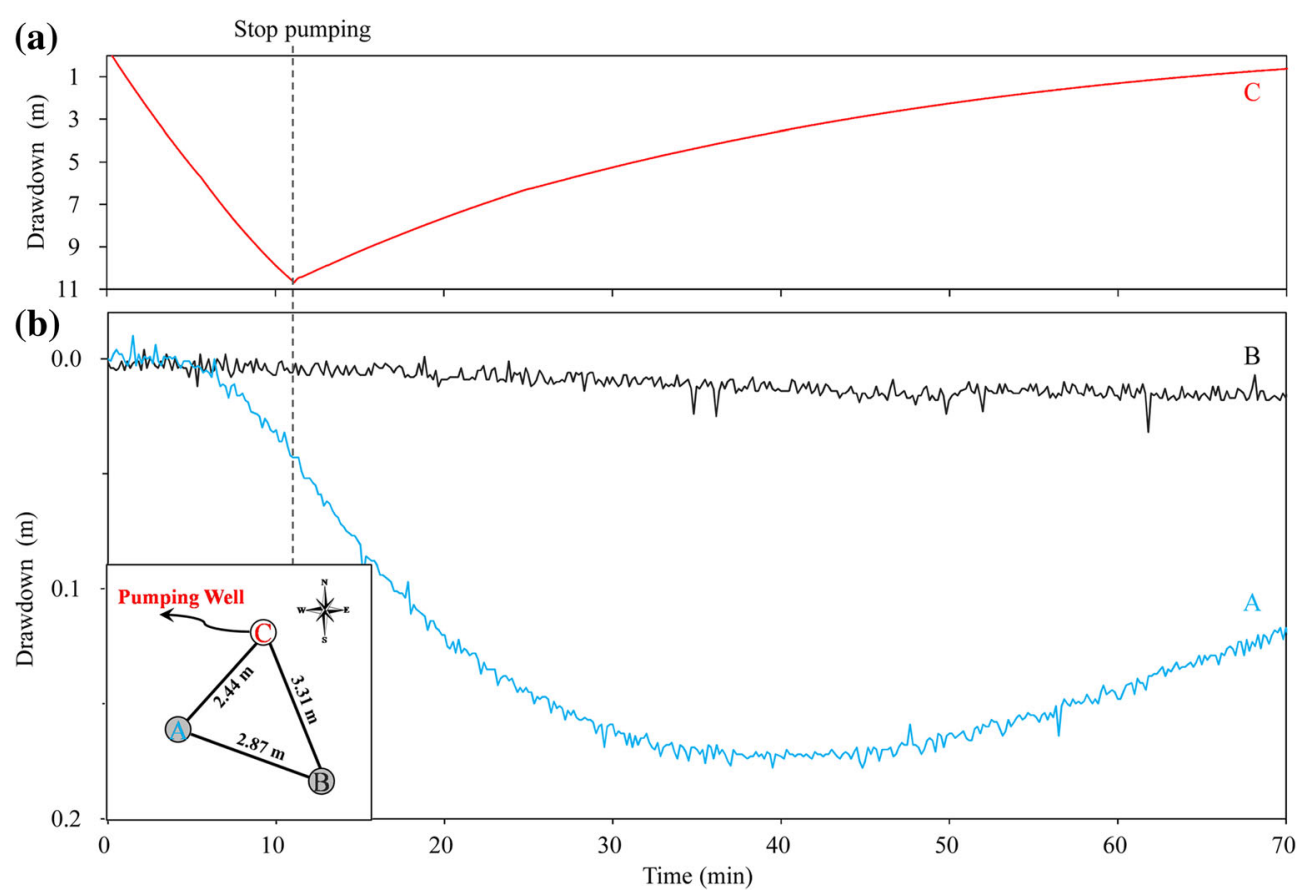

measured velocities were corrected by the empirical formula developed by Lee et al. (2012)

$V_{\mathrm{a}}=a V_{\mathrm{m}}-b$

where $V_{\mathrm{a}}$ is the actual flow velocity and $V_{\mathrm{m}}$ is the measured flow velocity. Coefficients $a$ and $b$ are 1.05 and 0.144 respectively for a 4 -in $(10.16-\mathrm{cm})$ diameter well. The corrected flowmeter data were then analyzed by the FLASH program
(Molz et al. 1989; Day-Lewis et al. 2011). The transmissivity obtained from the hydraulic tests and the corrected flow velocities in the borehole were used to calculate the section transmissivity $\left(T_{i}\right)$, which is the transmissivity of the $i$-th section in the open hole. The thickness of each section is $25 \mathrm{~cm}$. The profile of section transmissivity reveals the ease of inflow to the borehole (Fig. 5). The most permeable zone in well A is located at $19.75-20 \mathrm{~m}$ depth, which is consistent with a high fracture density zone found in the acoustic televiewer image;
Fig. 4 Drawdown versus time for the second hydraulic test at a the pumping well $\mathrm{A}$ and $\mathbf{b}$ observation wells $\mathrm{B}$ and $\mathrm{C}$
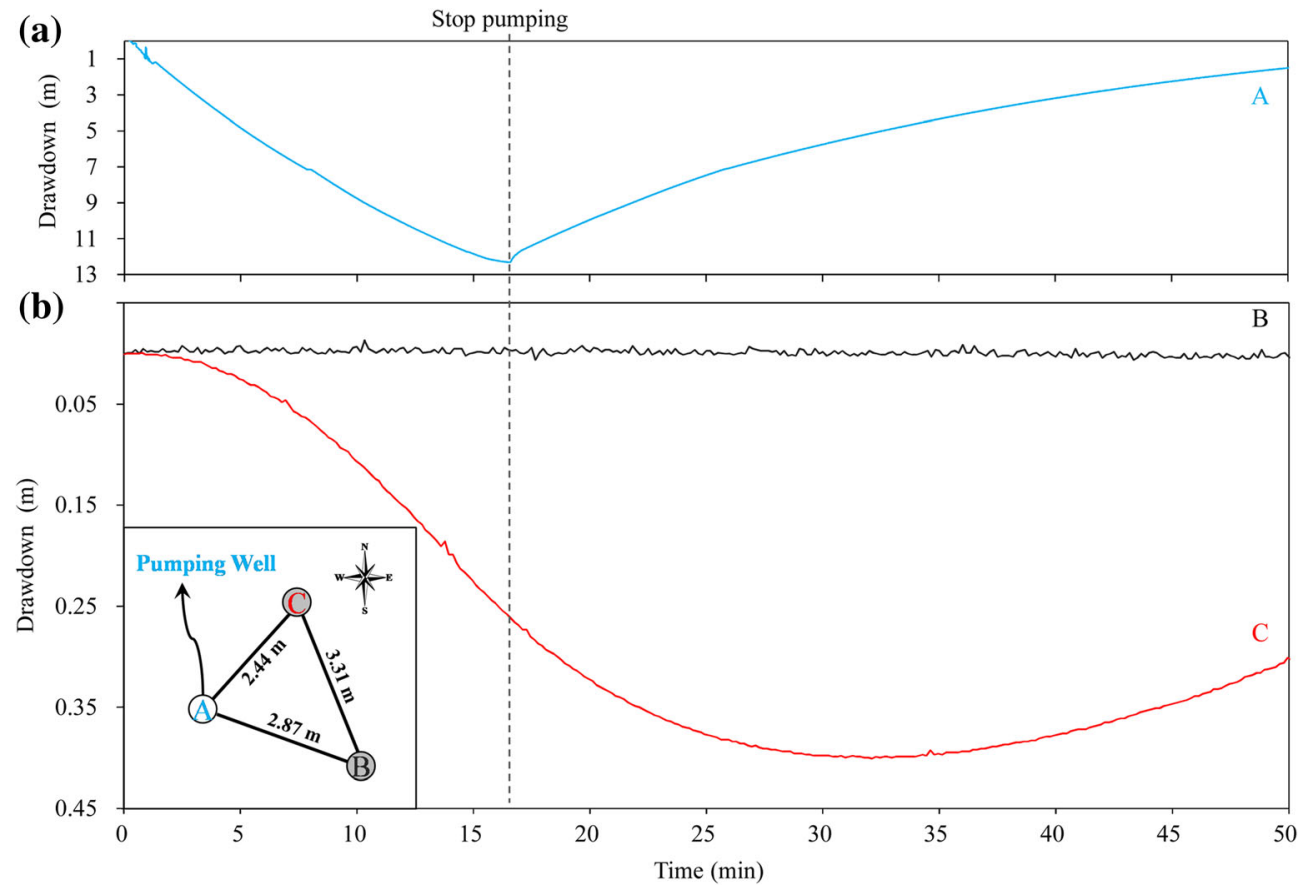
Fig. 5 Acoustic televiewer log, fracture index from the rock core, vertical distribution of borehole flow rate and section transmissivity from the flowmeter measurement at well $\mathrm{A}$. The thickness of each section is $25 \mathrm{~cm}$. The fracture index is defined as the number of fractures per meter of the rock core

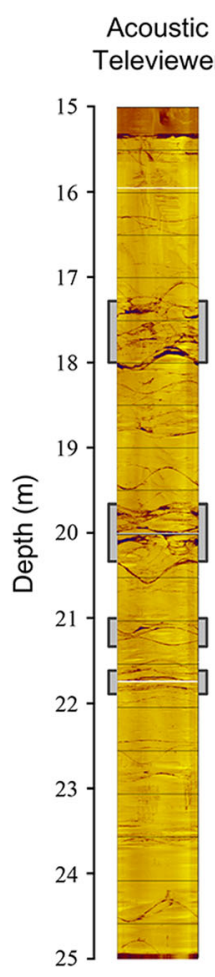

Fracture Index

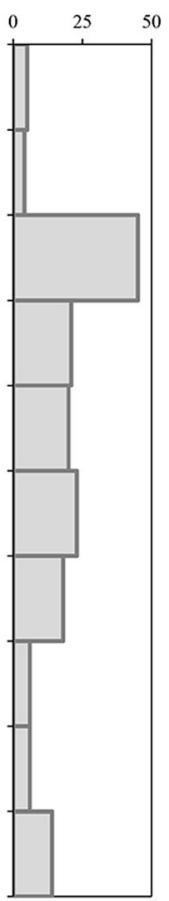

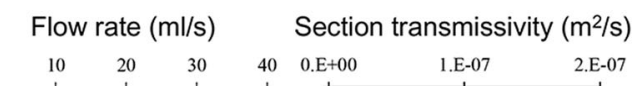

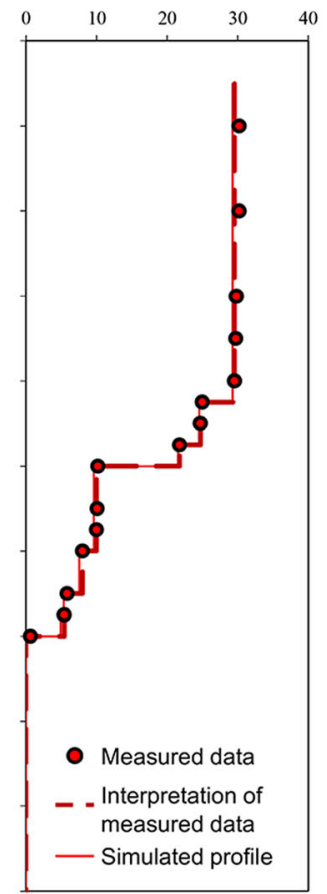

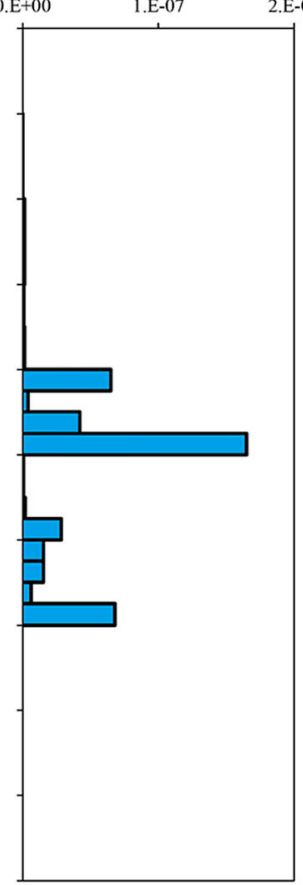

however, the section transmissivity obtained from the flowmeter measurement at the depth of 17.3-18.0 m, where the fracture density is the highest, is considerably low.

In the well $\mathrm{C}$, the flowmeter measurements were implemented between the depths of 16 and $24 \mathrm{~m}$ with a pumping rate of $23.3 \mathrm{ml} / \mathrm{s}$ (Fig. 6). The results indicated the depth of the most permeable zones at the depths of 21.25-21.75 and 23.5-
$23.75 \mathrm{~m}$, respectively. The permeable zone at the depth of 23.5-23.75 $\mathrm{m}$ coincides with a zone of high fracture density found in the acoustic televiewer image; however, the fracture density is quite low in the other permeable zone at the depth of 21.25-21.75 m.

The heat-pulse flowmeter measurement results indicated that a few zones of high fracture density found in the rock
Fig. 6 Acoustic televiewer log, fracture index from the rock core, vertical distribution of borehole flow rate and section transmissivity from the flowmeter measurement at well $\mathrm{C}$. The thickness of each section is $25 \mathrm{~cm}$. The fracture index is defined as the number of fractures per meter of the rock core

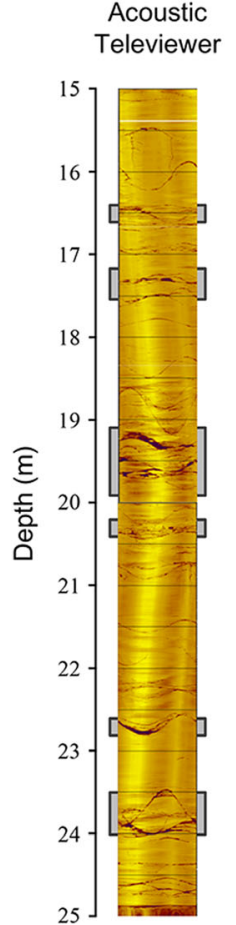

Fracture Index

\section{Flow rate $(\mathrm{ml} / \mathrm{s})$}

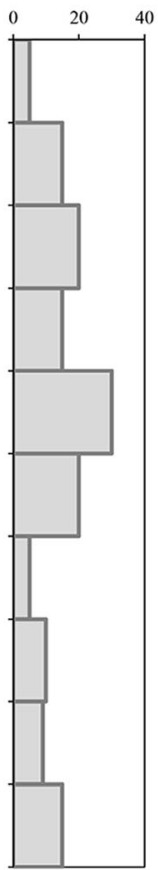

Section transmissivity $\left(\mathrm{m}^{2} / \mathrm{s}\right)$

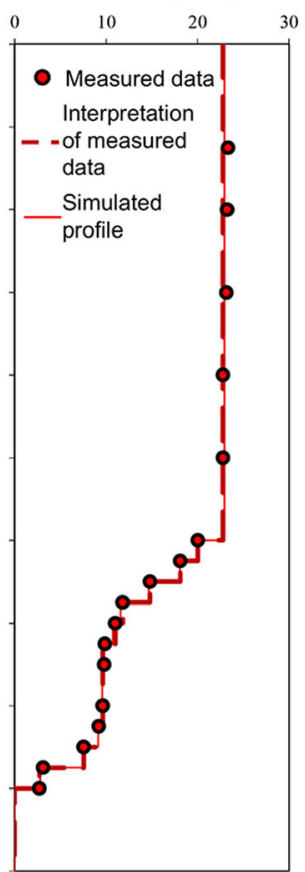

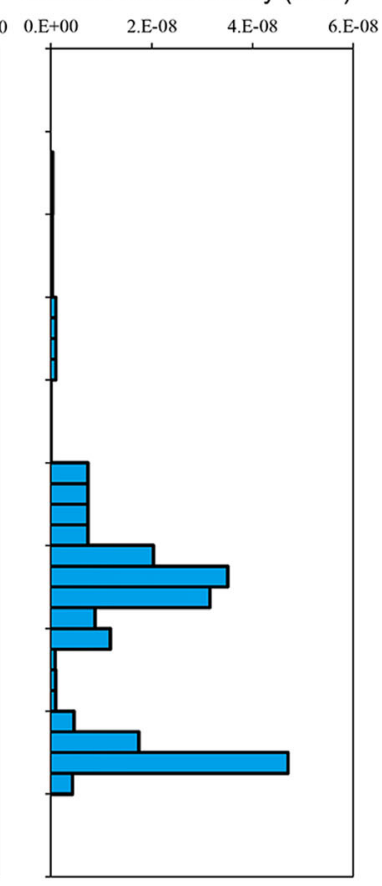


core or televiewer image are consistent with the permeable sections detected by the flowmeter, while most are not permeable. The low permeability in zones of high fracture density is attributed to the limited extent or discontinuity of fractures. These zones are often found to have fractures filled with silty clay, blocking the fracture flow. According to Paillet et al. (1987), the indirect techniques for delineating a permeable zone based on the fracture density from the rock core and televiewer image may not be reliable.

\section{Nano-iron tracer test}

nZVI has been used in the remediation of groundwater contaminants for decades. Previous studies indicated that nZVI particles can be transported at least $1-2.5 \mathrm{~m}$ in unconsolidated deposits (He et al. 2010; Johnson et al. 2013; Kocur et al. 2014). This study intends to adopt nZVI slurry as a tracer for the direct detection of fracture flow paths. Here watersoluble polyethyleneimine is used as a nanoparticle surfactant.

There are three advantages of using nZVI slurry. Firstly, nZVI particle size is only $50-100 \mathrm{~nm}$, and thus it can be transported by the groundwater in fractured rock. Secondly, the conductivity of the nZVI slurry is about $3120 \mu \mathrm{S} / \mathrm{cm}$, which is much higher than that of local groundwater, ranging from 590 to $620 \mu \mathrm{S} / \mathrm{cm}$. The difference make it possible to monitor the variation of fluid conductivity for detecting the migration of nZVI slurry. Last but the most important, nZVI is magnetic and can be attracted by a magnet. This feature provides the chance to design a magnet array assembly for attracting nZVI particles at the tracer inlet to delineate the location of connecting permeable fractures in observation wells.

\section{Laboratory experiment}

Before the field test, a laboratory test was conducted to examine the feasibility of using nZVI slurry as a tracer. The rock fracture was simulated by a three-layer system composed of a thin permeable sand layer confined by two thick clay layers. Two screened tubes were installed in the three-layer system to simulate the injection well and the observation well. The water flow in the permeable layer was driven by a higher hydraulic head in the injection tube. The dissolved oxygen is approximately $3 \mathrm{mg} / \mathrm{L}$ and the fluid conductivity is $115 \mu \mathrm{S} / \mathrm{cm}$. As the laboratory flow test was carried out in an aerobic environment, some nZVI particles were oxidized in 2-3 weeks, but most remained as zero-valent iron after 6 months. Due to the magnetic attractive forces between particles and the gravity effect, most nZVI particles tend to aggregate together and precipitate at the bottom of the injection tube; however, a small portion of nZVI particles migrated into the permeable sand layer, and some nZVI slurry did migrate to the observation tube. The tracer breakthrough was recorded by a fluid conductivity sensor and the location of incoming tracer was delineated by the nano-iron attracted to the magnet array in the observation tube. The process of laboratory nano-iron tracer test paved the way to further experiment in the field.

\section{Field experiment}

Based on permeable zones delineated by the flowmeter in the borehole, a nano-iron tracer test was designed to investigate the fracture flow paths between well A and well C, where the hydraulic interconnection was confirmed by the hydraulic tests. Well A was selected as an injection well, while well C was an observation well. A fluid conductivity logger (Aqua TROLL 200) was placed at the depth of $19.9 \mathrm{~m}$ adjacent to the most permeable zone delineated by the flowmeter measurement in well A. Two fluid conductivity loggers were installed, respectively, at the depths of 21.5 and $23.6 \mathrm{~m}$ in well $\mathrm{C}$, where the most permeable zones are located. A 10-m magnet array assembly was placed between the depth of 14 and $24 \mathrm{~m}$ in well $\mathrm{C}$ to detect where and how much the iron nanoparticles were attracted in well C. The magnet array assembly is composed of a $2-\mathrm{mm}$ steel cable, 10 centralizers and 100 pieces of $2.95 \times 1.25 \mathrm{~cm} \mathrm{NdFeB}$ magnets. The interval is $10 \mathrm{~cm}$ between magnets and $1 \mathrm{~m}$ between centralizers. In addition, a plumb was placed at the bottom of the magnet array to avoid bending effect due to magnetic attractive forces between magnets. The general setting of the tracer test is illustrated in Fig. 7.

Twenty liters of nZVI slurry, which consists of approximately $111 \mathrm{~g}$ of nZVI particles, were prepared in the laboratory. Since the nZVI particles can be oxidized and loose the magnetism in the shallow subsurface environment, it is important to reduce the duration of the tracer test; therefore, a force gradient with a divergent flow field was generated by increasing the well water level to the wellhead through the injection at well A. The injection well A was flushed before the test in order to reduce fine particles in the borehole and rock fractures. When the well water level had recovered, the nZVI slurry was mixed with the ambient water obtained from a distant well and injected through a plastic tube to the depth of $19.5 \mathrm{~m}$ at a rate of $0.11 \mathrm{~L} / \mathrm{s}$. Immediately after the injection of nZVI slurry, which took about $14 \mathrm{~min}$, the ambient water was continuously injected through the tube. When the well overflowed at $19 \mathrm{~min}$, the plastic tube was pulled out. Then ambient water was injected into the well head to maintain the overflowed condition throughout the test.

The original hydraulic gradient between wells $\mathrm{A}$ and $\mathrm{C}$ under the natural condition was about $0.01 \mathrm{~m} / \mathrm{m}$, but it increased rapidly due to continuous injection. When well A overflowed, the hydraulic head rose approximately $10.4 \mathrm{~m}$. As a result, the hydraulic gradient between wells A and C increased to $2.19 \mathrm{~m} / \mathrm{m}$ and remained at this level until the end of the test. 
Fig. 7 Schematic diagram of the field setting of the nano-iron tracer test. The blue-shaded areas represent the permeable zones detected by the flowmeter. The orange-shaded areas label the depths of injection tube, conductivity sensors and magnet array, respectively

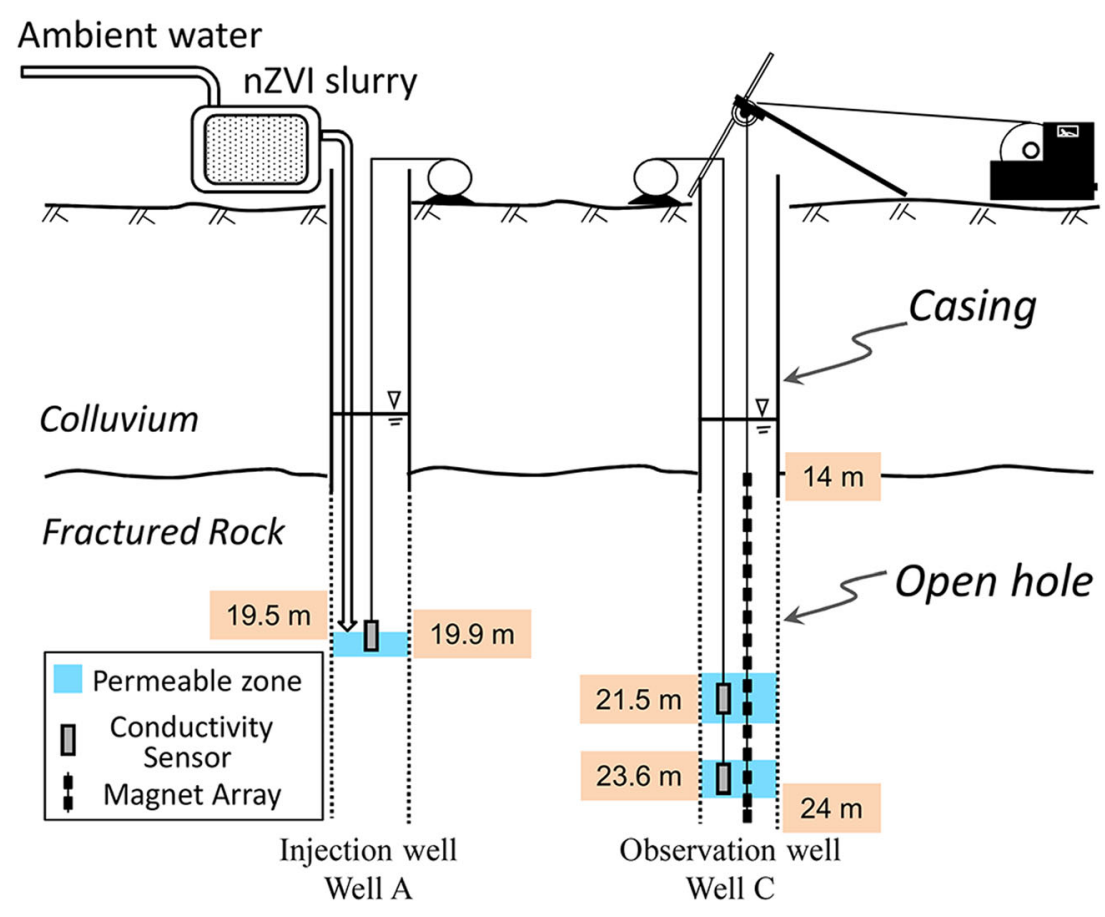

Prior to the injection of the nZVI slurry, the fluid conductivity at the depth of $19.9 \mathrm{~m}$ in well A was $600-610 \mu \mathrm{S} / \mathrm{cm}$ (Fig. 8a). It rose up abruptly to $1,754 \mu \mathrm{S} / \mathrm{cm} 3 \mathrm{~min}$ after the injection, then declined rapidly to $691 \mu \mathrm{S} / \mathrm{cm}$. After the injection tube was pulled out at $19 \mathrm{~min}$, the fluid conductivity rose up slowly to $2,088 \mu \mathrm{S} / \mathrm{cm}$, but declined again to the background level $3 \mathrm{~h}$ later. It remained at this level until the end of the tracer test.
In the observation well $\mathrm{C}$, the fluid conductivity was recorded at the depth of 21.5 and $23.6 \mathrm{~m}$ during the tracer test (Fig. 8b). The conductivity stayed at about $648 \mu \mathrm{S} / \mathrm{cm}$ at the depth of $21.5 \mathrm{~m}$ throughout the test. This phenomenon suggested that nano-iron slurry did not reach well $\mathrm{C}$ through any fractures above the depth of $21.5 \mathrm{~m}$. On the other hand, the fluid conductivity at $23.6 \mathrm{~m}$ deep in well $\mathrm{C}$ began to rise rapidly $11.5 \mathrm{~min}$ after the injection, indicating the first arrival
Fig. 8 Changes in fluid conductivity of the well water during the nano-iron tracer test. a Time series of fluid conductivity recorded at the depth of $19.9 \mathrm{~m}$ in the injection well $A$. b Time series of fluid conductivity recorded at the depth of 21.5 and $23.6 \mathrm{~m}$ respectively in the observation well $C$. The horizontal axes are the elapsed time after the tracer injection

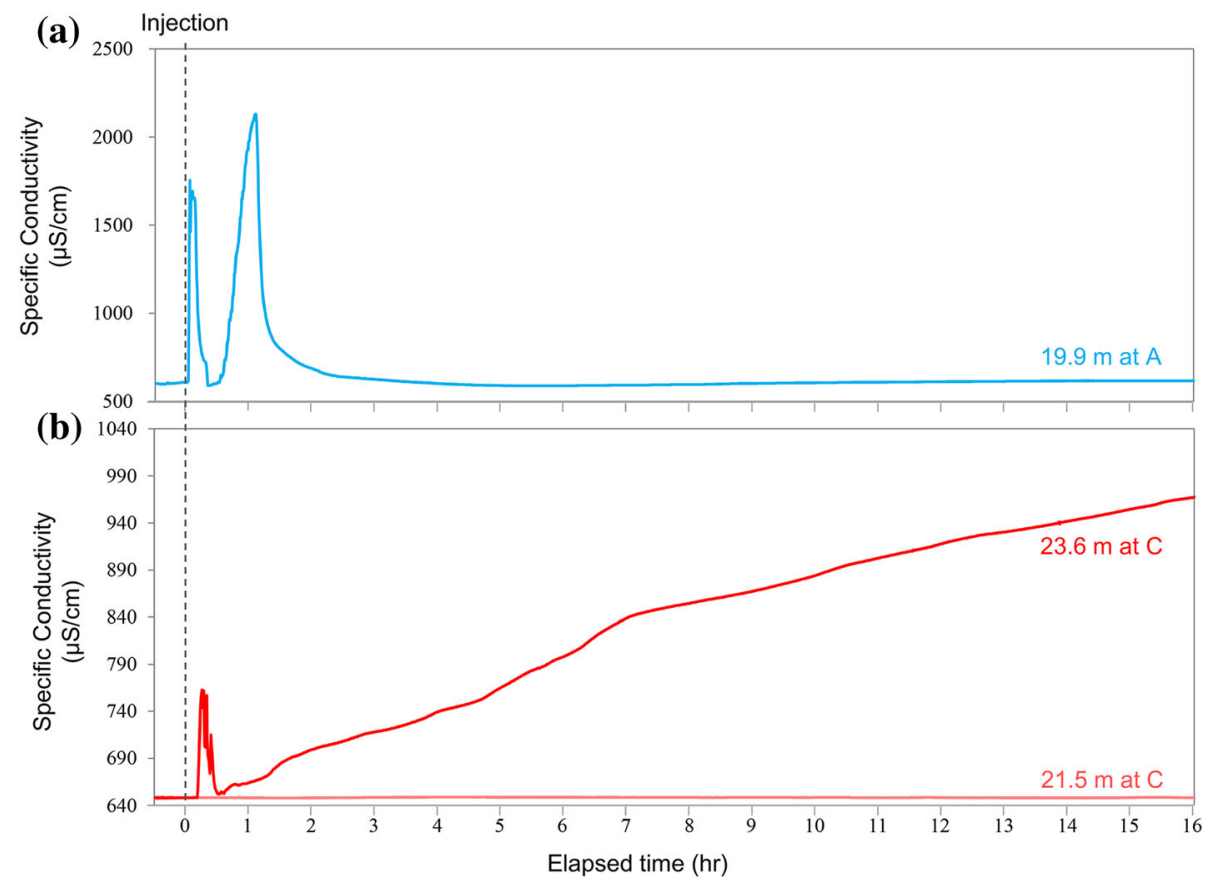


of the nZVI slurry in the observation well. It reached a peak of $762 \mu \mathrm{S} / \mathrm{cm}$ at $16 \mathrm{~min}$, but declined rapidly to $652 \mu \mathrm{S} / \mathrm{cm}$ at $31 \mathrm{~min}$. Then the fluid conductivity increased monotonously until the end of the tracer test.

After the tracer test was completed, the magnet array assembly was pulled out from the observation well to examine the depth and the weight of nZVI attracted to the magnets. Nearly all of the accumulated iron nanoparticles were attracted to the magnets at the depth between 22.9 and $24 \mathrm{~m}$ (Fig. 9). The weight of accumulated iron nanoparticles attracted to a piece of magnet ranged from 0.4 to $2.4 \mathrm{mg}$. The total weight of attracted nZVI particles was $12.5 \mathrm{mg}$, which was approximately $0.01 \%$ of the injected nZVI particles.

\section{Interpretation of test results}

\section{Migration of nZVI slurry}

According to the monitoring data during the tracer test, two conductivity pulses were recorded at the depth of $19.9 \mathrm{~m}$ in injection well A (Fig. 8a). The pulse changes were likely associated with the migration of the nZVI slurry. Initially the nZVI slurry injected through the tube would migrate upward and downward as a result of turbulent flow due to the injection (Fig. 10). The first rapid rise of fluid conductivity at the depth of $19.9 \mathrm{~m}$ was attributed to the downward movement of nZVI slurry. When more ambient water and less nZVI slurry was injected, the fluid conductivity declined rapidly. After the well overflowed at $19 \mathrm{~min}$, ambient water was injected into the wellhead, instead of through the tube. Since the density of polyethyleneimine is greater than that of groundwater, the nZVI slurry that migrated upward and suspended above the injection point in well A would have moved downward, resulting in the second conductivity pulse at the depth of $19.9 \mathrm{~m}$.

In the observation well $\mathrm{C}$, there was only one conductivity pulse recorded at $23.6 \mathrm{~m}$ depth (Fig. 8b). It was likely caused by the arrival of the first pulse of nZVI slurry through the connected permeable fracture from injection well $\mathrm{A}$. It is noted that the duration of the first conductivity pulse was $18.5 \mathrm{~min}$ in well $\mathrm{A}$ and $19 \mathrm{~min}$ in well $\mathrm{C}$ by comparing the changes in fluid conductivity recorded in the two wells (Fig. 11). Such a similar duration of the conductivity changes in the two wells suggested the dominance of advection in the transport of the nZVI slurry through the connected fracture between wells $\mathrm{A}$ and $\mathrm{C}$. Hydrodynamic dispersion of the nZVI slurry was not significant, possibly due to the short migration distance and less tortuosity in the permeable fracture (Grisak and Pickens 1980; Huyakorn et al. 1983).

The largest increase during the first conductivity pulse in well $\mathrm{C}$ is only about one-tenth of that in well A, suggesting
Fig. 9 The acoustic televiewer $\log$, profile of the section transmissivity, and profile of the weight of iron nanoparticles attracted to the magnet in the observation well C

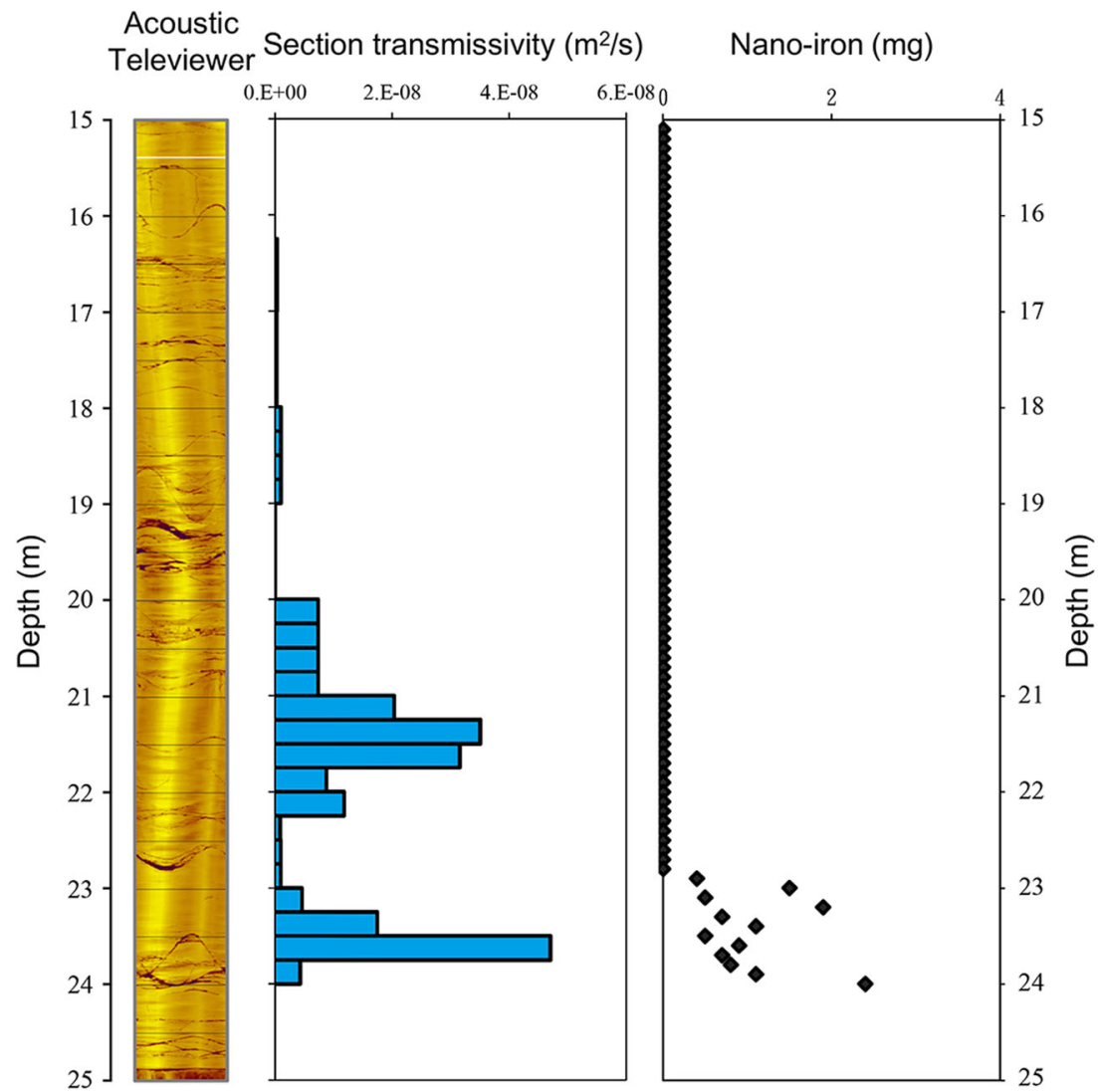




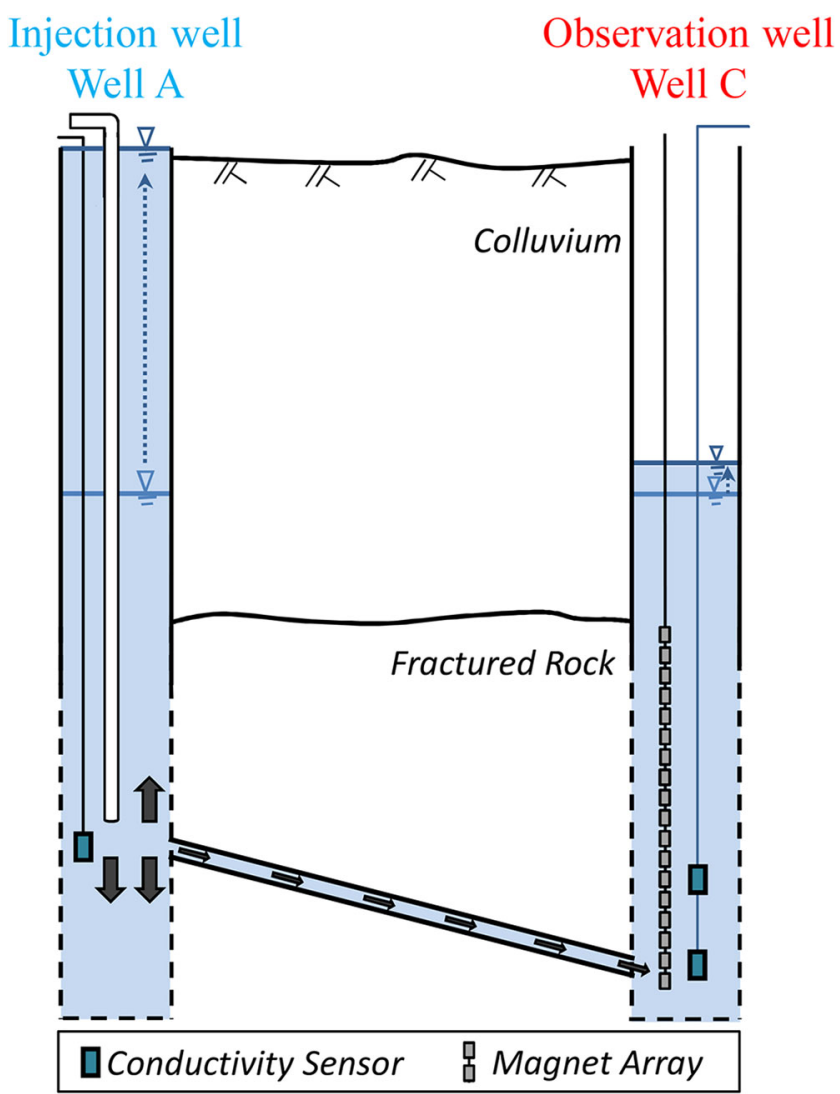

Fig. 10 Schematic diagram showing the migration of nZVI tracer between well $A$ and well $C$ during the tracer test. While most of injected nZVI slurry settled at the bottom of the well A, a small amount migrated radially through a permeable fracture away from the injection well A due to the divergent flow field. When the nZVI particles arrived in the observation well $\mathrm{C}$, they were attracted to the magnet array at the tracer inlet

that most of the injected nZVI slurry in well A did not migrate to well $\mathrm{C}$. This phenomenon is possibly attributed to the dominance of downward migration of nZVI slurry in well A due to the gravity effect (Kanel et al. 2008), as observed during the laboratory test. Only a small amount would follow the hydraulic gradient to migrate laterally through the permeable fracture. Therefore, the fluid conductivity recorded at the depth of $23.6 \mathrm{~m}$ in well $\mathrm{C}$ was significantly lower than that recorded at the depth of $19.9 \mathrm{~m}$ in well A. The conductivity pulse recorded in well $\mathrm{C}$ was followed by a continuous increase until the end of the tracer test (Fig. 8b). The increase was probably caused by the downward migration and accumulation of incoming nZVI slurry at the hole bottom due to the gravity effect.

The nZVI particles attracted to the magnet array in well C were distributed from the depth of 22.9-24 m, which is consistent with large changes in fluid conductivity observed at the depth of $23.6 \mathrm{~m}$. According to the laboratory test, $\mathrm{NdFeB}$ magnets have a strong magnetic attractive force, and thus most incoming nZVI particles could be attracted by magnets. The tracer test results suggested the nano-iron tracer inlet is near the depth of 22.9-24 $\mathrm{m}$ in well $\mathrm{C}$. By integrating the

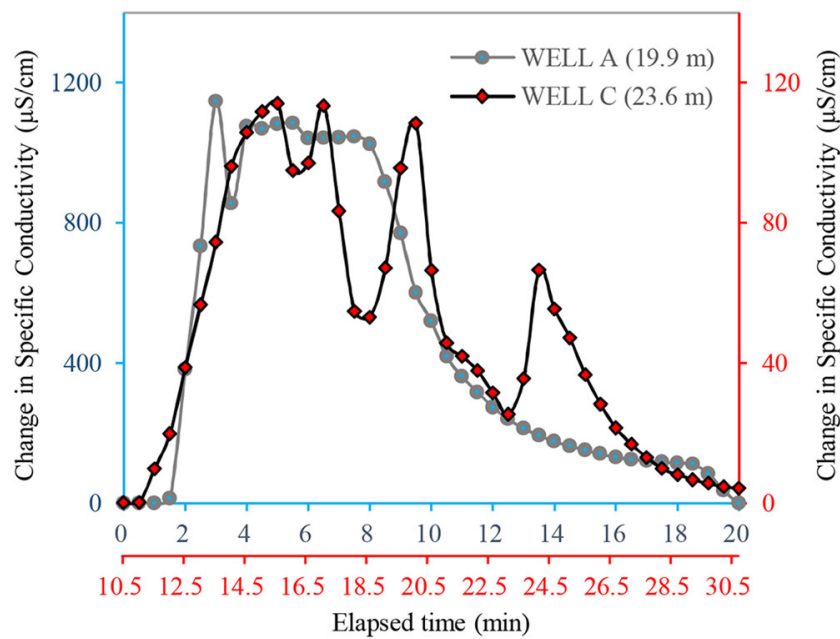

Fig. 11 Comparison of changes in specific conductivity at the injection well $A$ and the observation well $C$. Fluid conductivity changes at the depth of $19.9 \mathrm{~m}$ in well A are represented by blue circles (gray line). Fluid conductivity changes at the depth of $23.6 \mathrm{~m}$ in well $\mathrm{C}$ are represented by red diamonds (black line). The first and second horizontal axes are the elapsed time after the tracer injection in well A (blue) and well C (red), respectively

flowmeter measurement results with the tracer test results (Figs. 5 and 9), the most possible connected permeable fracture zone extends from the depth of $19.75-20.0 \mathrm{~m}$ in well A to the depth of $23.25-23.75 \mathrm{~m}$ in well $\mathrm{C}$.

\section{Hydraulic parameters}

Analysis of flowmeter measurement data indicated that $38 \%$ of borehole flow in well A comes from the permeable zone between the depths of 19.75 and $20.0 \mathrm{~m}$ where the section transmissivity is $1.65 \times 10^{-7} \mathrm{~m}^{2} / \mathrm{s}$ and the equivalent hydraulic conductivity is $6.6 \times 10^{-7} \mathrm{~m} / \mathrm{s}$ (Fig. 5). Similarly, $26 \%$ of borehole flow in well $\mathrm{C}$ comes from the permeable zone between the depths of 23.25 and $23.75 \mathrm{~m}$, where the transmissivity is $6.45 \times 10^{-8} \mathrm{~m}^{2} / \mathrm{s}$ and the equivalent hydraulic conductivity is $1.29 \times 10^{-7} \mathrm{~m} / \mathrm{s}$ (Fig. 6).

The connected permeable fracture is likely to extend from the depth of 19.75-20.0 $\mathrm{m}$ in well A to the depth of 23.25 $23.75 \mathrm{~m}$ in well C (Fig. 10). The horizontal distance between the two wells is $2.44 \mathrm{~m}$ (at the ground surface). According to the results of an acoustic televiewer log, the mean deviation is $0.5^{\circ}$ to the direction of $\mathrm{N} 224^{\circ}$ and the start-end distance is $0.22 \mathrm{~m}$ in well A. The mean deviation is $0.2^{\circ}$ to the direction of $\mathrm{N}_{002^{\circ}}$ and the start-end distance is $0.08 \mathrm{~m}$ in well C. Considering the deviations of the two wells, the estimated length of the connected permeable fracture is approximately $4.62 \mathrm{~m}$

The nZVI slurry was detected approximately $1 \mathrm{~min}$ after the injection at the depth of $19.9 \mathrm{~m}$ in well $\mathrm{A}$ and $11.5 \mathrm{~min}$ after the injection at the depth of $23.6 \mathrm{~m}$ in well C. Thus, the duration of nano-iron tracer migration through the connected 
fracture is about $10.5 \mathrm{~min}$. If the dispersion effect is ignored, the seepage velocity of nZVI slurry in the connected fracture between wells $\mathrm{A}$ and $\mathrm{C}$, estimated by the length of the connected fracture divided by the migration time, is approximately $7.33 \times 10^{-3} \mathrm{~m} / \mathrm{s}$.

When the nZVI slurry arrived in well $\mathrm{C}$, the hydraulic head rose $8.19 \mathrm{~m}$ in well $\mathrm{A}$ at $11.5 \mathrm{~min}$. The hydraulic gradient $(\nabla h$ ), calculated by the average change of hydraulic head divided by the length of migration along the permeable fracture, was approximately 0.89 . As the fractures are partially filled with unconsolidated deposits (based on the core samples), the effective porosity of the connected permeable fracture is assumed to be 0.2 . The hydraulic conductivity $(K)$ can be calculated based on Darcy's law

$K=-\frac{v n_{\mathrm{e}}}{\nabla h}$

where $v$ is the seepage velocity and $n_{\mathrm{e}}$ is the effective porosity. Here the hydraulic conductivity in the connected fracture between wells A and C is estimated to be $1.65 \times 10^{-3} \mathrm{~m} / \mathrm{s}$. As the transmissivity of the connected permeable zone in wells $\mathrm{A}$ and $\mathrm{C}$ ranges from $6.45 \times 10^{-8}$ to $1.65 \times 10^{-7} \mathrm{~m}^{2} / \mathrm{s}$, the effective thickness of the connected permeable fracture is estimated to be $0.039-0.1 \mathrm{~mm}$ approximately. In other words, the groundwater flow between the two wells is likely to concentrate on a permeable thin fracture.

\section{Discussions}

The tracer test results indicated that nZVI particles attracted to the magnet array provided a direct evidence to delineate the position of connected permeable fracture in the observation well. Nevertheless, the weight of attracted nZVI particles is only a little more than $0.01 \%$ of the total weight of injected nZVI particles, suggesting that most of iron nanoparticles did not migrate from the injection well to the observation well. The outcome was attributed to the settlement of iron nanoparticles at the bottom of the injection well as well as the radial migration of nZVI slurry from the injection well through the anisotropic fractured media.

The magnetic attractive forces and van der Waals forces are known to affect the aggregation and gelation between nZVI particles, causing precipitation in the water environment (Comba and Sethi 2009). Phenrat et al. (2007) indicated that nZVI particles can aggregate to micrometer-size aggregates and precipitate from solution rapidly. The addition of the dispersant polyethyleneimine can form a colloidal system to reduce the aggregation of iron nanoparticles. During the tracer injection, however, the nZVI slurry was mixed with a large amount of groundwater, affecting the stability of the colloidal system. Most iron nanoparticles in the diluted slurry were probably aggregated and precipitated to the bottom of the injection well. Approximately 1.5 years after the tracer test, the injection well A was inspected by the video camera. A large amount of black iron particles were found at the bottom of the borehole, indicating most of the nZVI did settle to the bottom of the injection well.

Only a small amount of the injected nZVI slurry migrated away from the well A through the permeable fracture. The radial migration in the permeable fractured media driven by the injection may significantly dilute the iron nanoparticles. In this experimental test, only a tiny but measurable amount of injected nZVI particles arrived in the observation well, where they were attracted by the magnet at the entrance. Such a tiny mass recovery would significantly restrict the potential application of nano-iron tracer. Further improvement in the tracer test design is needed to enhance the mass recovery of nZVI particles for any long distance test in the future.

Based on the monitoring data, four peaks of fluid conductivity changes were recorded at the depth $23.6 \mathrm{~m}$ in observation well C (Fig. 11). This phenomenon could be explained by multiple connected permeable fractures between the two wells. The migration of nZVI slurry through multiple fractures is anticipated to show velocity dispersion effects due to the difference in fracture opening, filling materials, and tortuosity of the flow paths. However, a similar duration of the first conductivity pulse change was recorded in wells A and C, as shown in Fig. 11, suggesting that the dispersion of nZVI slurry in the fracture zone was not significant. Therefore, the nZVI slurry was likely to migrate through a single fracture between wells $\mathrm{A}$ and $\mathrm{C}$. The four peaks could be attributed to the temporary blocking of the nZVI aggregates by the deposits in the route of migration along the connected fracture. With increasing fluid pressure gradient, the aggregates would move again along the fracture. Thus, the aggregates of nZVI slurry could be separated by the blocking process, generating multiple peaks of conductivity change in the observation well.

The hydraulic conductivity of the connected fracture estimated from the tracer test is more than 2,000 times higher than the equivalent hydraulic conductivity of the permeable zone obtained from the hydraulic test and flowmeter test in wells A and C. Such a result suggested a highly permeable thin fracture dominating the groundwater flow and transport process in the fractured rock. The conventional hydraulic analysis that yields the average hydraulic properties over the whole aquifer or a permeable section may not reflect the actual hydraulic properties.

\section{Conclusions}

The field experiment of a novel characterization approach has demonstrated that nano-iron can be used as a tracer to directly detect fracture flow paths between boreholes. The injected iron nanoparticles were attracted to the magnet at the tracer 
inlet in the observation well, providing quantitative information for delineating the location of incoming fracture flow. The test results indicated that the flow path between the injection and observation wells was likely to be a highly permeable thin fracture. The depth of the tracer inlet at the observation well is consistent with that of a highly permeable zone delineated by the heat-pulse flowmeter. Apparently the nano-iron tracer test, in conjunction with heat-pulse flowmeter measurements, has the potential to characterize the preferential flow paths in fractured rock; however, further improvement is needed in the design of the tracer test to enhance the mass recovery of iron nanoparticles in order to implement a test over a long distance.

Acknowledgements The authors would like to acknowledge the Central Geological Survey, Industrial Technology Research Institute and Sinotech Inc. for their assistance in the field. We also appreciate the reviews by Paul Hsieh and an anonymous reviewer. The study is supported by a research grant from the Ministry of Science and Technology of Taiwan (MOST 104-3113-M-002-002).

Open Access This article is distributed under the terms of the Creative Commons Attribution 4.0 International License (http:// creativecommons.org/licenses/by/4.0/), which permits unrestricted use, distribution, and reproduction in any medium, provided you give appropriate credit to the original author(s) and the source, provide a link to the Creative Commons license, and indicate if changes were made.

\section{References}

Barton CA, Zoback MD, Moos D (1995) Fluid-flow along potentially active faults in crystalline rock. Geology 23:683-686. doi:10.1130/ 0091-7613(1995)023<0683:FFAPAF>2.3.Co;2

Basirico S, Crosta GB, Frattini P, Villa A, Godio A (2015) Borehole flowmeter logging for the accurate design and analysis of tracer tests. Ground Water 53(Suppl 1):3-9. doi:10.1111/gwat.12293

Bennett P, He F, Zhao D, Aiken B, Feldman L (2010) In situ testing of metallic iron nanoparticle mobility and reactivity in a shallow granular aquifer. J Contam Hydrol 116:35-46. doi:10.1016/j.jconhyd. 2010.05.006

Braester C, Thunvik R (1984) Determination of formation permeability by double-packer tests. J Hydrol 72:375-389. doi:10.1016/00221694(84)90090-8

Chen CS (1986) Solutions for radionuclide transport from an injection well into a single fracture in a porous formation. Water Resour Res 22:508-518. doi:10.1029/WR022i004p00508

Coleman TI, Parker BL, Maldaner CH, Mondanos MJ (2015) Groundwater flow characterization in a fractured bedrock aquifer using active DTS tests in sealed boreholes. J Hydrol 528:449-462. doi:10.1016/j.jhydrol.2015.06.061

Comba S, Sethi R (2009) Stabilization of highly concentrated suspensions of iron nanoparticles using shear-thinning gels of xanthan gum. Water Res 43:3717-3726. doi:10.1016/j.watres.2009.05.046

Day-Lewis FD, Johnson CD, Paillet FL, Halford KJ (2011) A computer program for flow-log analysis of single holes (FLASH). Groundwater 49:926-931. doi:10.1111/j.1745-6584.2011.00798.x

Grisak GE, Pickens JF (1980) Solute transport through fractured media, 1: the effect of matrix diffusion. Water Resour Res 16:719-730. doi: 10.1029/WR016i004p00719

He F, Zhao D, Paul C (2010) Field assessment of carboxymethyl cellulose stabilized iron nanoparticles for in situ destruction of chlorinated solvents in source zones. Water Res 44:2360-2370. doi:10.1016/j. watres.2009.12.041

Hess AE (1986) Identifying hydraulically conductive fractures with a slow-velocity borehole flowmeter. Can Geotech J 23:69-78. doi: 10.1139/t86-008

Huyakorn PS, Lester BH, Mercer JW (1983) An efficient finite-element technique for modeling transport in fractured porous-media, 1: single species transport. Water Resour Res 19:841-854. doi:10.1029/ WR019i003p00841

Johnson RL, Nurmi JT, O’Brien Johnson GS, Fan D, O’Brien Johnson RL, Shi Z, Salter-Blanc AJ, Tratnyek PG, Lowry GV (2013) Fieldscale transport and transformation of carboxymethylcellulosestabilized nano zero-valent iron. Environ Sci Technol 47:15731580. doi: $10.1021 / \mathrm{es} 304564 \mathrm{q}$

Kanel SR, Goswami RR, Clement TP, Barnett MO, Zhao D (2008) Two dimensional transport characteristics of surface stabilized zerovalent iron nanoparticles in porous media. Environ Sci Technol 42:896-900. doi:10.1021/es071774j

Klepikova MV, Le Borgne T, Bour O, Gallagher K, Hochreutener R, Lavenant N (2014) Passive temperature tomography experiments to characterize transmissivity and connectivity of preferential flow paths in fractured media. J Hydrol 512:549-562. doi:10.1016/j. jhydrol.2014.03.018

Kocur CM, Chowdhury AI, Sakulchaicharoen N, Boparai HK, Weber KP, Sharma P, Krol MM, Austrins L, Peace C, Sleep BE, O'Carroll DM (2014) Characterization of nZVI mobility in a field scale test. Environ Sci Technol 48:2862-2869. doi:10.1021/ es4044209

Lee TP, Chia YP, Chen JS, Chen HE, Liu CW (2012) Effects of free convection and friction on heat-pulse flowmeter measurement. J Hydrol 428:182-190. doi:10.1016/j.jhydrol.2012.02.001

Molz FJ, Morin RH, Hess AE, Melville JG, Guven O (1989) The impeller meter for measuring aquifer permeability variations: evaluation and comparison with other tests. Water Res 25:1677-1683. doi:10.1029/ WR025i007p01677

National Research Council (NRC) (1996) Rock fractures and fluid flow: contemporary understanding and applications. National Academy Press, Washington, DC

Neuman SP (2005) Trends, prospects and challenges in quantifying flow and transport through fractured rocks. Hydrogeol J 13:124-147. doi: 10.1007/s10040-004-0397-2

Novakowski KS, Lapcevic PA (1994) Field measurement of radial solute transport in fractured rock. Water Resour Res 30:37-44. doi:10. 1029/93wr02401

Paillet FL, Hess AE, Cheng CH, Hardin E (1987) Characterization of fracture permeability with high-resolution vertical flow measurements during borehole pumping. Ground Water 25:28-40. doi:10. 1111/j.1745-6584.1987.tb02113.x

Papadopulos IS, Cooper HH (1967) Drawdown in a well of large diameter. Water Res 3:241. doi:10.1029/WR003i001p00241

Phenrat T, Saleh N, Sirk K, Tilton RD, Lowry GV (2007) Aggregation and sedimentation of aqueous nanoscale zerovalent iron dispersions. Environ Sci Technol 41:284-290. doi:10.1021/es061349a

Read T, Bour O, Bense V, Le Borgne T, Goderniaux P, Hochreutener R, Lavenant N, Boschero V (2013) Characterizing groundwater flow and heat transport in fractured rock using fiber-optic distributed temperature sensing. Geophys Res Lett 40:2055-2059. doi:10. 1002/grl.50397

Sharifi Haddad A, Hassanzadeh H, Abedi J, Chen Z, Ware A (2015) Characterization of scale-dependent dispersivity in fractured formations through a divergent flow tracer test. Ground Water 53:149155. doi:10.1111/gwat.12187

Sun YP, Li XQ, Zhang WX, Wang HP (2007) A method for the preparation of stable dispersion of zero-valent iron nanoparticles. Colloid Surface A 308:60-66. doi:10.1016/j.colsurfa.2007.05.029 
Swanson SK, Bahr JM, Bradbury KR, Anderson KM (2006) Evidence for preferential flow through sandstone aquifers in southern Wisconsin. Sediment Geol 184:331-342. doi:10.1016/j.sedgeo.2005.11.008

Van Meir N, Jaeggi D, Herfort M, Loew S, Pezard P, Lods G (2007) Characterizing flow zones in a fractured and karstified limestone aquifer through integrated interpretation of geophysical and hydraulic data. Hydrogeol J 15:225-240. doi:10.1007/s10040-006-0086-4

Varanasi P, Fullana A, Sidhu S (2007) Remediation of PCB contaminated soils using iron nanoparticles. Chemosphere 66:1031-1038. doi:10. 1016/j.chemosphere.2006.07.036

Wang CB, Zhang WX (1997) Synthesizing nanoscale iron particles for rapid and complete dechlorination of TCE and PCBs. Environ Sci Technol 31:2154-2156. doi:10.1021/es970039c
Williams JH, Johnson CD (2000) Borehole-wall imaging with acoustic and optical televiewers for fractured-bedrock aquifer investigations. Seventh International Symposium on Borehole Geophysics for Minerals, Geotechnical, and Groundwater Applications, Houston, TX, October 1, 2000, pp 43-53

Williams JH, Paillet FL (2002) Using flowmeter pulse tests to define hydraulic connections in the subsurface: a fractured shale example. J Hydrol 265:100-117. doi:10.1016/S0022-1694(02)00092-6

Zhao J (1998) Rock mass hydraulic conductivity of the Bukit Timah granite, Singapore. Eng Geol 50:211-216. doi:10.1016/S00137952(98)00021-0 